\title{
ELIMINATING SEX DISCRIMINATION IN EDUCATIONAL INSTITUTIONS: DOES TITLE IX REACH EMPLOYMENT?
}

Title IX of the Education Amendments of $1972^{1}$ was among the many remedial measures enacted by the Ninety-second Congress to address congressional concerns about gender-based discrimination. $^{2}$ Title IX prohibits discrimination on the basis of sex in educational programs or activities receiving federal financial assistance. ${ }^{3}$ Each agency distributing educational funds is "authorized and directed" to promulgate rules and regulations ensuring that federal aid recipients comply with the congressional mandate. ${ }^{4}$ The ultimate sanction for noncompliance is the termination of federal education funds available to the institution. ${ }^{5}$

Because most educational programs are administered by the Department of Education (ED) ${ }^{6}$ attention thus far has been focused (1976)).

1 Pub. L. No. 92-318, 86 Stat. 373 (codified at 20 U.S.C. \$\$1681-1686

2 See, e.g., Equal Employment Opportunity Act of 1972, Pub. L. No. 92-261, 86 Stat. 103 (codified in scattered sections of 5, 42 U.S.C.) (strengthening, inter alia, title VII of the Civil Rights Act of 1964, 42 U.S.C. $\$ \$ 2000 \mathrm{e}$ to $2000 \mathrm{e}-17$ (1976, Supp. I 1977 \& Supp. II 1978)); State and Local Fiscal Assistance Act of 1972, Pub. L. No. 92-512, $\S 122,86$ Stat. 919 (codified at 31 U.S.C. $\$ 1242$ (1976)) (prohibiting sex discrimination in programs financed by revenue sharing funds); Economic Opportunity Amendments of 1972, Pub. L. No. 92-424, \$23, 86 Stat. 688 (codified at 42 U.S.C. \$2971c (1976)) (prohibiting sex discrimination in programs financed by the Office of Economic Opportunity); Equal Rights Amendment, H.R.J. Res. 208, 92d Cong., 2d Sess., 86 Stat. 1523 (1972).

320 U.S.C. $\$ 1681$ (a) (1976). For a more complete discussion of the statutory language, including the many exceptions following the general prohibition, see notes 23-42 infra \& accompanying text. See generally Comment, Implementing Title IX: The HEW Regulations, 124 U. PA. L. REv. 806, 807-18 (1976).

420 U.S.C. $\$ 1682$ (1976).

5 Compliance with any requirement adopted pursuant to this section may be effected (I) by the termination of or refusal to grant or to continue assistance under such program or activity to any recipient as to whom there has been an express finding on the record, after opportunity for hearing, of a failure to comply with such requirement, but such termination or refusal shall be limited to the particular political entity, or part thereof, or other recipient as to whom such a finding has been made, and shall be limited in its effect to the particular program, or part thereof, in which such noncompliance has been so found....

Id.

6 The Department of Education (ED) was created by the Department of Education Organization Act, Pub. L. No. 96-88, 93 Stat. 668 (codified at 20 U.S.C. $\$$ 3401-3510 (Supp. III 1979)). Education-related compliance efforts, including title IX enforcement, were formerly handled by the Department of Health, Education, and Welfare (HEW). 20 U.S.C. $\$ 344 I$ (a) (3) (Supp. III 1979). See [1979] U.S. Code Cong. \& AD. NEws 1514, 1549-52. This Comment 
on the ED regulations implementing the title IX prohibition.? These regulations, resting upon a broad interpretation of title IX, proscribe sex discrimination against both students and employees of educational institutions. ${ }^{8}$ Although it is unclear whether such employment regulations are within the authority granted ED by Congress, there was little opposition to the proposed regulations when they were issued in $1975 .^{9}$ ED's authority to regulate employment discrimination under title IX was challenged briefly during con-

will refer to $\mathrm{ED}$ and its regulations as the relevant authorities, although the regulations were originally promulgated by HEW, see note 9 infra, and ED has only been functioning since May 4, 1980. Exec. Order No. 12,212, 45 Fed. Reg. 29,557 (1980).

7 34 C.F.R. $\$ 106$ (1980).

At least two other agencies have issued regulations to effectuate the purposes of title IX. Department of Agriculture (USDA) regulations, for example, prohibit sex discrimination in educational programs assisted by USDA funds. 7 C.F.R. $\S 15 \mathrm{a}(1980)$. The Small Business Administration has also used title IX as partial authority for regulations requiring nondiscrimination in its financial assistance programs. 13 C.F.R. $\$ 113$ (1980).

${ }^{8}$ See 34 C.F.R. $\$ 106$, Subpart C (discrimination in admission and recruitment); Subpart $\mathrm{D}$ (discrimination in education programs and activities); Subpart $E$ (discrimination in employment in educational programs and activities) (1980).

As already noted, see note 7 supra, the Department of Agriculture (USDA) has also promulgated title IX regulations. They, too, reach employment discrimination. 7 C.F.R. \$15a, Subpart E (1980). These employment regulations have never been challenged by the affected institutions; nor has their enforcement ever been a major priority, though they may have been used in some complaint reviews or compliance agreements that have not gone through the general counsel's office. Telephone interview with Lonnie C. Rich, Office of General Counsel, USDA (September 15, 1980). At least part of this underutilization can be explained by the prior existence of sex discrimination regulations reaching employment practices, 7 C.F.R. $\$ 18$ ( 1980 ), promulgated under the Smith-Lever Act, 7 U.S.C. $\$ \$ 341-349$ (1976) (authorizing USDA's cooperative extension work program).

9 Title IX was signed into law by the President on June 23, 1972. Education Amendments of 1972, Pub. L. No. 92-318, 86 Stat. 235, 381 (codified in scattered sections of $7,12,16,20,29,42$ U.S.C.). The regulations were issued in proposed form by HEW on June 20, 1974. 39 Fed. Reg. 22,228 (1974). Former HEW Secretary Caspar W. Weinberger explained the two-year delay by noting that the 37 -word prohibitory language of the statute had to be translated into specific and comprehensive regulations addressing many major policy issues; that all HEW had to work from was a "very muddy congressional intent"; and that various avenues for interest-group participation had to be provided. Sex Discrimination Regulations: Hearings Before the Subcomm. on Postsecondary Education of the House Comm. on Education and Labor, 94th Cong., Ist Sess. 437-38, 460 (1975) (testimony of HEW Secretary Weinberger) [hereinafter cited as 1975 Hearings]. After an extended period of public participation during which the agency received over 9,700 written comments, final regulations were issued in June 1975. 40 Fed. Reg. 24,128-45 (1975) (codified at 45 C.F.R. $\$ 86$ (1979)). According to an HEW official, not one of the written comments forwarded to the agency suggested that Congress did not intend to cover employment under title IX. See 1975 Hearings, supra, at 479 (testimony of Peter Holmes). The regulations became effective on July 21, 1975, more than a year after they were issued in proposed form. 40 Fed. Reg. 24, 128 (1975). After the Department of Education began functioning, see note 6 supra, it issued identical regulations. 34 C.F.R. $\$ 106$ (1980). 
gressional hearings examining the final regulations, ${ }^{10}$ but Congress did not take any formal action, ${ }^{11}$ and the regulations took effect without modification. Since 1975, however, a few members of Congress ${ }^{12}$ and several affected educational institutions ${ }^{13}$ have questioned whether Congress intended the general prohibition of sex discrimination in title IX to encompass the employment practices of educational institutions. No definitive answer to this question has been provided by Congress or the courts. ${ }^{14}$

Until recently, all federal courts considering the validity of ED's employment regulations, including the Ninth Circuit decision in Seattle University $v$. HEW, ${ }^{15}$ held that ED exceeded its statutory authority by issuing title IX regulations reaching employment discrimination. Each of these courts concluded that neither the plain language of the statute nor the legislative history of title IX supports ED's contention that it has the authority to regulate employment at educational institutions. ${ }^{16}$ These decisions have severely limited ED's enforcement program under title IX. ${ }^{17}$

10 See 1975 Hearings, supra note 9, at 406-08 (statement of Janet L. Kuhn). Ms. Kuhn later formalized her understanding of congressional intentions in Kuhn, Title IX: Employment and Athletics are Outside HEW's Jurisdiction, 65 Geo. L.J. 49 (1976).

11 This congressional inaction does not constitute approval of the regulations. See notes 84-99 infra \& accompanying text.

12 See notes 101-02 infra \& accompanying text.

13 See, e.g., cases cited in note 15 infra.

14 The Supreme Court recently agreed to resolve the issue. Seattle Univ. v. IEW, 621 F.2d 992 (9th Cir.) (per curiam), cert. granted sub nom. United States Dep't of Educ. v. Seattle Univ., 49 U.S.L.W. 3409 (U.S. Dec. 1, 1980) (No. 80-493).

15621 F.2d 992 (9th Cir.) (per curiam), cert. granted sub nom. United States Dep't of Educ. v. Seattle Univ., 49 U.S.L.W. 3409 (U.S. Dec. 1, 1980) (No. 80-493); accord, Romeo Community Schools v. HEW, 600 F.2d 581 (6th Cir.), cert. denied, 444 U.S. 972 (1979); Junior College Dist. v. Califano, 597 F.2d 119 (8th Cir.), cert. denied, 444 U.S. 972 (1979); Islesboro School Camm. v. Califano, 593 F.2d 424 (1st Cir.), cert. denied, 444 U.S. 972 (1979); Grove City College v. Harris, No. 78-1293 (W.D. Pa. June 26, 1980); Kneeland v. Bloom Township High School Dist., 484 F. Supp. 1280 (N.D. Ill. 1980); Sobel v. Yeshiva Univ., 477 F. Supp. 1161 (S.D.N.Y. 1979); Auburn School Dist. v. HEW, 19 Fair Empl. Prac. Cas. 1504 (D.N.H. 1979), appeal dismissed, No. 79-1261 (Ist Cir. 1980); Board of Educ. v. HEW, 19 Fair Empl. Prac. Cas. 457 (N.D. Ohio 1979); University of Toledo v. HEW, 464 F. Supp. 693 (N.D. Ohio 1979); McCarthy v. Burkholder, 448 F. Supp. 41 (D. Kan. 1978). See also Kuhn, supra note 10, at 50-62; Note, Title IX of the Education Amendments of 1972: Issues Reach the Courts, 18 WASHBURN L.J. 310, 317-19 (1979).

16 The federal district court opinion in Romeo Community Schools v. HEW, 438 F. Supp. 1021 (E.D. Mich. 1977), affd, 600 F.2d 581 (6th Cir.), cert. denied, 444 U.S. 972 (1979), and the First Circuit opinion in Islesboro School Comm. v. Califano, 593 F.2d 424 (Ist Cir.), cert. denied, 444 U.S. 972 (1979), provide the most comprehensive justifications for this view and have been substantially relied on by other courts.

17 The Office for Civil Rights (OCR) has suspended normal enforcement of its employment regulations, and has instructed $\mathrm{ED}$ regional offices to proceed 
The Second and Fifth Circuits, however, recently refused to follow this otherwise unanimous authority. In North Haven Board of Education v. Hufstedler, ${ }^{18}$ the Second Circuit, after an exhaustive examination of the statutory language and the legislative history, concluded that Congress did intend to reach the employment practices of educational institutions under title IX. ED's employment regulations were thus valid and enforceable. In Dougherty County School System v. Harris, ${ }^{19}$ a much briefer opinion issued just four days after the North Haven decision, the Fifth Circuit adopted a middle ground. Recognizing that the current regulations apply to all employees of an educational system as long as any program or activity in the system receives federal assistance, the three-judge panel decided that ED exceeded its statutory authority when it issued these general regulations. The Court did not adopt, however, the majority view that ED can regulate only student-related sex discrimination. Rather, it suggested that regulations "limited to employees whose compensation is defrayed in whole or in part by federal assistance or even to those who work in programs receiving federal aid or with students who are federally assisted" may properly be within the scope of title IX. ${ }^{20}$

only in limited cases. Petition for a Writ of Certiorari to the United States Court of Appeals for the First Circuit, at 12 \& n.9, Islesboro School Comm. v. Califano, 593 F.2d 424 (Ist Cir.), cert. denied, 444 U.S. 972 (1979). In June 1979, 507 (55.6\%) of the 912 title IX cases pending before OCR concerned alleged employment discrimination. ED was prevented from acting on many of these complaints because they emanated from those judicial districts in which the regulations had been invalidated. Id. 11. As of September 1980, 158 (30.4\%) of the 519 pending title IX cases concerned employment discrimination; their enforcement was similarly hindered. Telephone FOIA Request, see 5 U.S.C. $\$ 552$ (1976 \& Supp. II 1978), from OCR, Office of Planning and Compliance Operations, Analysis and Evaluation Division, Reports and Analysis Branch (October 6, 1980). Cases in which federal funds directly support employees, see note 28 infra, or where ED's "infection theory" is applicable, see note 111 infra, are still being processed. Petition for a Writ of Certiorari to the United States Court of Appeals for the First Circuit, supra, at 12 \& n.9.

18629 F.2d 773 (2d Cir. 1980); accord, Piascik v. Cleveland Museum of Art, 426 F. Supp. 779 (N.D. Ohio 1976) (dictum). Piascik was the first court opinion to discuss title IX's application to employment discrimination, albeit in a lengthy footnote concerned with another issue. While discussing whether to imply a private right of action for vindicating violations of title IX, the court noted that "[s]ection 1681(a), and the legislative history supporting it, express a powerful Congressional intent to eradicate sex discrimination in non-religious, non-military, co-educational programs, including, but certainly not limited to sex discrimination in employment in educational activities." 426 F. Supp. at 780, $781 \mathrm{n.1}$ (emphasis added). Subsequent court opinions have given little weight to this dictum. See, e.g., Islesboro School Comm. v. Califano, 593 F.2d 424, 429 (1st Cir.) (court unconvinced that Piascik "stands squarely for the proposition" that title IX covers employment, and even if it does, it is "unpersuasive"), cert. denied, 444 U.S. 972 (1979).

10622 F.2d 735 (5th Cir. 1980).

20 Id. 736; see id. 737-38. 
The courts' different conclusions regarding the validity of ED's employment regulations have resulted from their different assumptions about, and descriptions of, the language and legislative history of title IX. Parts I and II of this Comment examine these differences and demonstrate that they are indicative of the general uncertainty surrounding title IX's employment coverage. The Comment argues that, although the plain language of title IX and the legislative debate preceding its enactment suggest that employees are indeed covered under the title IX umbrella, they are ultimately inconclusive in resolving whether Congress intended to authorize ED's employment regulations. It is necessary, therefore, to examine the congressional purposes underlying title IX.21 This examination, in part III of the Comment, demonstrates that Congress did intend to provide another sanction for employment discrimination in educational institutions when it enacted title IX; ED's employment regulations therefore should be held valid and enforceable. ${ }^{22}$

\section{The Plain Language of Title IX}

\section{A. The General Prohibition}

Section 1681(a) of title IX provides that "[n]o person in the United States shall, on the basis of sex, be excluded from participation in, be denied the benefits of, or be subjected to discrimination

21 The courts have previously examined these purposes in only a cursory fashion. See, e.g., North Haven Bd. of Educ., 629 F.2d at 785; Romeo Community Schools v. HEW, 438 F. Supp. 1021, 1032-34 (E.D. Mich. 1977), affd, 600 F.2d 581 (6th Cir.), cert. denied, 444 U.S. 972 (1979).

22 The employment issue is but one of several questions that have been raised concerning the scope and enforcement of title IX. Much has been written, for example, about title IX's impact on intercollegiate athletics. See, e.g., Cox, Intercollegiate Athletics and Title IX, 46 Geo. WASH. L. Rev. 34 (1977); Note, Sex Discrimination and Intercollegiate Athletics: Putting Some Muscle on Title IX, 88 YAr.E L.J. 1254 (1979) [hereinafter cited as YArE Note]. Another area of contention concerns whether Congress intended a private right of action under title IX. This question was recently answered in the affirmative by the Supreme Court. Cannon v. University of Chicago, 441 U.S. 677 (1979). See, e.g., Comment, A Private Right of Action Under Title IX: Cannon v. University of Chicago, 57 DEN. L.J. 437 (1980); Note, Title IX: No Longer an Empty Promise-Cannon v. University of Chicago, 29 DE PAUr L. REv. 263 (1979); Comment, Implication of a Private Right of Action Under Title IX of the Education Amendments of 1972, $73 \mathrm{Nw}$. U.L. REv. 772 (1978). The inadequate enforcement of title IX by HEW's Office for Civil Rights has also been the focus of much debate. See, e.g., Note, The Enforcement Provisions for Title IX of the Education Amendments of 1972 Can be Strengthened to Make Title IX Regulations More Effective, 49 TEMP. L.Q. 207 (1975); Note, Implied Rights of Action to Enforce Civil Rights: The Case for a Sympathetic View, 87 Yar. I.J. 1378, 1404-06 (1978). 
under any education program or activity receiving Federal financial assistance." 23

ED has consistently argued that the statutory term "no person" includes employees at the affected educational institution. ${ }^{24}$ Most courts, however, applying the doctrine of ejusdem generis, ${ }^{25}$ have rejected ED's interpretation. ${ }^{26}$ Noting that the benefited class may not, "on the basis of sex, be excluded from participation in, be denied the benefits of, or be subjected to discrimination under" any federally financed education program, ${ }^{27}$ these courts have concluded that students alone satisfy these criteria ${ }^{28}$ and that section 1681 is "indirect, if not obscure," ${ }^{29}$ in its reference to teachers, faculty or other employees of educational institutions.

2320 U.S.C. $\$ 1681$ (a) (1976).

The starting point in any case requiring statutory construction is, of course, the language of the statute itself. Southeastern Community College v. Davis, 442 U.S. 397, 405 (1979). See generally Franlfurter, Some Reflections on the Reading of Statutes, 47 Colum. L. REv. 527, 535 (1947) ("Though we may not end with the words in construing a disputed statute, one certainly begins there.").

24 See, e.g., 1975 Hearings, supra note 9 , at 477-78 (testimony of HEW Secretary Weinberger); Brief for Federal Appellants at 13-14, North Haven Bd. of Educ. v. Hufstedler, 629 F.2d 773 (2d Cir. 1980).

This expansive interpretation reflects the general principle that civil rights statutes should be read broadly; exceptions to such statutes should be narrowly construed. See $3 \mathrm{~J}$. Sutherrand, Statutes and Statutory Construction $\$ 72.05$ (4th ed. C. Sands 1973). Compare Daniel v. Paul, 395 U.S. 298, $307-08$ (1969) and Jones v. Alfred H. Mayer Co., 392 U.S. 409, 437 (1968) with A.H. Phillips, Inc. v. Walling, 324 U.S. 490, 493 ( 1945).

25 When specific words follow general words, "the general words are construed to embrace only objects similar in nature to those objects enumerated by the . . . specific words." 2 A J. SutherLAND, supra note 24 , at $\S 47.17$ (footnote omitted). Cf. R. Dickerson, The Interpretation and Application of StatuTEs 249 (1975) (ejusdem generis not actually a rule of construction, but a tool for judicial law-making).

${ }^{26}$ See, e.g., Brunswick School Bd. v. Califano, 449 F. Supp. 866, 870 (D. Me. 1978), aff'd, Islesboro School Comm. v. Califano, 593 F.2d 424 (Ist Cir.), cert. denied, 444 U.S. 972 (1979).

The Supreme Court, for its part, has until now avoided defining the term "person." At most, the Court has recognized that students fall within the benefited class. See Cannon v. University of Chicago, 441 U.S. 677, 693-94 (1979).

2720 U.S.C. $\$ 1681(\mathrm{a})(1976)$.

28 See, e.g., Islesboro School Comm. v. Califano, 593 F.2d 424, 426 (Ist Cir.), cert. denied, 444 U.S. 972 (1979); Seattle Univ. v. HEW, 16 Fair Empl. Prac. Cas. 719, 720 (W.D. Wash. 1978), aff'd per curiam, 621 F.2d 992 (9th Cir. $1980)$, cert. granted sub nom. United States Dep't of Educ. v. Seattle Univ., 49 U.S.L.W. 3409 (U.S. Dec. 1, 1980) (No. 80-493); Romeo Community Schools v. HEW, 438 F. Supp. 1021, 1031 (E.D. Mich. 1977), aff'd, 600 F.2d 581 (6th Cir.), cert. denied, 444 U.S. 972 (1979). At least one exception to this holding has been admitted by these courts. Under their interpretation, the statute would protect a faculty member who has a government research grant, but only in his or her capacity as a direct beneficiary of the program. See, e.g., Islesboro School Comm., 593 F.2d at 426; Seattle Univ., 16 Fair Empl. Prac. Cas. at 720.

29 Romeo Community Schools v. HEW, 438 F. Supp. 1021, 1031 (E.D. Mich. 1977), aff'd, 600 F.2d 581 (6th Cir.), cert. denied, 444 U.S. 972 (1979). 
This reading is unnecessarily restrictive. Of the three categories of persons protected under section 1681(a)-participants, beneficiaries, and those "subjected to discrimination under" federally financed education programs-only the beneficiary class appears, on its face, to exclude employees. For while it is reasonable to argue that students are the only intended beneficiaries of federal education programs, it is equally reasonable to assume that teachers, as well as students, are participants in these programs. And at the very least, if men and women employed in a federally assisted educational program are paid unequal salaries or are considered differently for promotions based on their sex, such employees are arguably "subjected to discrimination under" the program. ${ }^{30}$ Indeed, at least one commentator has argued that this last category of protected persons-those "subjected to discrimination"-was designed to be a blanket provision prohibiting all forms of sex discrimination not covered by either of the first two categories. ${ }^{31}$ Thus, though an examination of the language employed in section 1681(a) is not conclusive, it does suggest that employees are included within the class of persons protected under the statute.

\section{B. The Exemptions in Section 1681}

ED also argues that Congress must have intended to cover employees because the list of exemptions provided in section $1681^{32}$ does not exclude employment from title IX's reach. ${ }^{33}$ Educational institutions challenging ED's regulations, on the other hand, argue

30 See Dougherty County School Sys. v. Harris, 622 F.2d 735, 738 (5th Cir. 1980); Petition for a Writ of Certiorari to the United States Court of Appeals for the Ninth Circuit, at 12-13, Seattle Univ. v. HEW, 621 F.2d 992 (9th Cir.) (per curiam), cert. granted sub nom. United States Dep't of Educ. v. Seattle Univ., 49 U.S.L.W. 3409 (U.S. Dec. 1, 1980) (No. 80-493).

31 Note, Sex Discrimination and Intercollegiate Athletics, 61 IowA L. Rev. 420,462 (1975).

3220 U.S.C. $\$ 1681$ (a)(1)-(9) (1976). Subsection (a)(1) provides that only admissions to institutions of vocational education, professional education, graduate higher education and public undergraduate higher education will be affected; subsection (a) (2) delays application of title IX to institutions modifying their single-sex status; subsection (a)(3) exempts religious institutions if title IX is contrary to the tenets of the religion; subsection (a)(4) exempts all military or merchant marine training institutions; subsection (a)(5) exempts traditionally single-sex institutions; subsection (a) (6) exempts membership practices of certain social fraternities and sororities and voluntary youth service organizations; subsections (a) (7)-(9) exempt activities related to Boys/Girls State/Nation conferences, father-son or mother-daughter activities (if reasonable opportunities exist for the opposite sex), and scholarships awarded to "beauty" pageant winners, respectively.

33 Brief for Federal Appellants at 14-15, North Haven Bd. of Educ. v. Hufstedler, 629 F.2d 773 (2d Cir. 1980). 
that because the statutory exemptions relate only to student activities or enrollment, only students are covered by the statute. ${ }^{34}$ It is not necessary to decide whether this conclusion is appropriate, however, because its premise-that all the exemptions are student-related-is flawed. The exemptions for religious and military institutions are blanket exclusions from the statute and do not specify studentrelated activities at such schools. ${ }^{35}$ In fact, portions of the congressional debate indicate that the religious and military school exemptions actually remove teachers at these institutions from coverage, thereby implying that teachers at other institutions are covered. ${ }^{36}$ Again, though the statutory language is not explicit, it does suggest that ED's employment regulations were at least implicitly authorized by Congress.

\section{G. The Fund Termination Provision}

Some opponents of the employment regulations argue that the plain language of section 1682, title IX's fund termination provision, precludes the possibility of implicit congressional authorization. Section 1682 provides that a cutoff of funds "shall be limited in its effect to the particular program, or part thereof, in which . . . noncompliance has been . . . found." 37 Although traditionally called a "pinpoint provision" for the termination of funds,

34 Several courts holding ED's regulations invalid have relied upon this argument. See, e.g., Islesboro School Comm. v. Califano, 593 F.2d 424, 426 (Ist Cir.), cert. denied, 444 U.S. 972 (1979); Seattle Univ. v. HEW, 16 Fair Empl. Prac. Cas. 719, 720 (W.D. Wash. 1978), aff'd per curiam, 621 F.2d 992 (9th Cir.), cert. granted sub nom. United States Dep't of Educ. v. Seattle Univ., 49 U.S.L.W. 3409 (U.S. Dec. 1, 1980) (No. 80-493); Romeo Community Schools v. HEW, 438 F. Supp. 1021, 1032 (E.D. Mich. 1977), aff'd, 600 F.2d 581 (6th Cir.), cert. denied, 444 U.S. 972 (1979).

35 North Haven Bd. of Educ., 629 F.2d at 778.

36 In a dialogue clearly referring to the title IX prohibition and its exemptions, Senators Pell and Bayh had the following conversation:

Mr. Pell. Would this apply to a parochial school where they have nuns as teachers?

Mr. BAYr. No. There is an explicit exception for educational institutions controlled by a religious organization.

Mr. PExx. Mr. President, I refer to a preparatory school such as Peekskill Military Institute which is at the high school level. Would that school be expected to have women teachers?

Mr. BAXH. All military schools are excluded.

118 Cong. REC. 5813 (1972).

3720 U.S.C. $\$ 1682$ (1976). See note 5 supra. 
many courts have labeled this a "program specific" sanction. ${ }^{38}$ Regardless of the label employed, educators and the majority of courts argue that because title IX's sanction has been so circumscribed, ED's regulatory authority under the statute must be equally limited. Regulation of an institution's employment practices, an area that is inherently nonprogram-specific, they argue, is therefore patently overbroad. $^{30}$

Judge Oakes, responding to this argument in North Haven Board of Education v. Hufstedler, refused to read the pinpoint provision into title IX's general prohibition.0 Instead, he found that limiting an eventual cutoff of funds to programs in which discriminatory practices are found need not also restrict ED's regulations prohibiting sex discrimination. Sections 1681 and 1682 have

38 See, e.g., Romeo Community Schools v. HEW, 438 F. Supp. 1021, 1033 (E.D. Mich. 1977), aff'd, 600 F.2d 581 (6th Cir.), cert. denied, 444 U.S. 972 (1979).

39 Id. The district court in Seattle Univ. v. HEW also held that the scope of $\$ 1681$ is "program specific" and therefore cannot be used to regulate employment. Its conclusion, however, was based on a narrow reading of the words "program or activity" in $\$ 1681$ itelf. 16 Fair Empl. Prac. Cas. 719, 720-21 (W.D. Wash. 1978), aff'd per curiam, 621 F.2d 992 (9th Cir.), cert. granted sub nom. United States Dep't of Educ. v. Seattle Univ., 49 U.S.L.W. 3409 (U.S. Dec. I, 1980) (No. 80-493).

There is an ongoing debate concerning the scope of "program or activity" as it appears in the prohibitory language of title IX. See text accompanying note 23 supra for the relevant text of $\$ 1681$. Most of this debate relies on similar language appearing in title VI. See note 44 infra for the relevant text of $\$ 2000 \mathrm{~d}$ of title VI. One view asserts that the words "program or activity" authorize regulations that are institutional in scope; for example, regulations covering an entire school district or institution of higher education would be acceptable. See, e.g., 1975 Hearings, supra note 9 , at 182-83 (colloquy between Representative Chisholm and Senator Bayh); cf. Lau v. Nichols, 414 U.S. 563, 568 (1974) (under title VI, entire school system referred to as "educational program"); Bossier Parish School Bd. v. Lemon, 370 F.2d 847, 852 (5th Cir. 1967) (under title VI, board "accepted federal financial assistance .... and thereby brought its school system within the class of programs subject to the section [2000d] prohibition against discrimination"). The opposing view, relying on Board of Pub. Instruction v. Finch, 414 F.2d 1068 (5th Cir. 1969), contends that "program" refers to individual grant-in-aid statutes. See id. 1077-78. Finch may be distinguishable, however, because the court was addressing only the title VI pinpoint provision limiting the statutory sanction and was not concerned with the prohibitory language of title VI. Alternatively, the Finch approach may be too strict because it forces the agency "to follow every federal dollar and determine whether it serves a discriminatory end." Note, Administrative Cutoff of Federal Funding Under Title VI: A Proposed Interpretation of "Program," 52 IND. L.J. 651, 667 (1977). See generally Comment, Board of Public Instruction v. Finch: Unwarranted Compromise of Title VI's Termination Sanction, 118 U. PA. L. Rev. 1113 (1970). In any case, the Seattle University court's reliance on $\$ 1681$ language is not as convincing as may first appear. But cf. Comment, HEW's Regulation Under Title IX of the Education Amendments of 1972: Ultra Vires Challenges, 1976 B.Y.U. L. REv. 133, 169-84 (Congress intended programmatic application of title IX); Note, Title IX Sex Discrimination Regulations: Impact on Private Education, 65 Ky. L.J. 656, 689-94 (1977) (title IX applies to programs, not institutions).

40629 F.2d at 785-86. 
different scopes-the former section is a broad prohibition of sex discrimination; the latter section contains a narrow fund termination provision. ${ }^{41}$ Reading these sections coterminously ignores the plain language of the statute. Moreover, employment practices are not the only nonprogram-specific activities that ED has attempted to regulate. Admissions to public undergraduate colleges, for example, may be discriminatory on an institution-wide basis, yet ED clearly has the statutory authority to ensure compliance in that area. ${ }^{42}$ If employees are covered by title IX, the scope of employment discrimination does not differ from undergraduate admissions in any relevant sense. Once again, therefore, the plain language of title IX cannot be said to conclusively determine whether or not employment discrimination is covered by the statute.

\section{The Legrslative History of Title IX}

Because the plain language of title IX is inconclusive, the events and words surrounding the statute's enactment must be considered.43 In this part of the Comment, therefore, the legislative history is examined to determine whether Congress intended to place employment discrimination within the reach of title IX.

\section{A. Pre-Enactment}

\section{The Link with Title VI}

There is no doubt that "[t]itle IX was patterned after Title VI of the Civil Rights Act of 1964." 44 In fact, title IX was originally

41 Center for National Policy Review, Memorandum to Project on Equal Protection Rights (April 7, 1975), reprinted in 1975 Hearings, supra note 9, at 191-96; accord, North Haven Bd. of Educ., 629 F.2d at 785-86.

42 Such admissions policies are explicitly covered by 20 U.S.C. $\$ 1681$ (a)(1) (1976). The Second Circuit used graduate admissions to illustrate this point, North Haven Bd. of Educ., 629 F.2d at 785, but such policies are more likely to be accomplished on a "program specific" basis than are undergraduate admissions.

43 Compare North Haven Bd. of Educ. v. Hufstedler, 629 F.2d 773, 778 (2d Cir. 1980) ("We hence must look beyond the language of the statute itself to determine its meaning.") with Islesboro School Comm. v. Califano, 593 F.2d 424, 426-27 (Ist Cir.) ("Since, however, employees are not expressly eliminated from the statute's coverage, and in light of HEW's strong urging that employees should be construed as coming within the coverage of the statute, we examine the legislative history for any illumination it can shed.") (emphasis in original), cert. denied, 444 U.S. 972 (1979). For an analysis of the "plain meaning rule," accompanied by the view that the context of the words must be considered, see R. Dickerson, supra note 25, at 229-33. But see Tennessee Valley Auth. v. Hill, 437 U.S. 153, 184 n.29 (1978) ("When confronted with a statute which is plain and unambiguous on its face, we ordinarily do not look to legislative history as a guide to its meaning.").

44 Camnon v. University of Chicago, 441 U.S. 677, 694 (1979) (footnote omitted). Title VI can be found in the Civil Rights Act of 1964, 42 U.S.C. $\$ \S 2000 \mathrm{~d}$ 
contemplated as a simple amendment adding the word "sex" to the words "race, color, or national origin" in title VI.45 Had that actually occurred, employment practices would be exempt from sex discrimination regulations because section $2000 \mathrm{~d}-3$ of title VI explicitly excludes employment from that title's scope. ${ }^{46}$ Apparently to avoid any "gutting" of title VI that might occur if it were opened to floor amendments, ${ }^{47}$ title IX's sponsors decided to propose separate educational amendments. Because changes were made in these amendments as they proceeded through the House and Senate, the version of title IX that was eventually enacted is similar, but not identical, to title VI. Those differences that do exist have become important because, "in the absence of specific Congressional indications to the contrary, [ED] has basically interpreted title IX consistently with interpretations of title VI in similar areas." 48

For the purpose of determining whether title IX covers employment discrimination, the most significant difference between titles IX and VI is that title IX contains no parallel provision exempting employment from its reach. ${ }^{49}$ Such a provision did ap-

to $2000 \mathrm{~d}-6$ (1976). Section $2000 \mathrm{~d}$ of that title provides that "[n]o person in the United States shall, on the ground of race, color, or national origin, be excluded from participation in, be denied the benefits of, or be subjected to discrimination under any program or activity receiving Federal financial assistance." 42 U.S.C. $\$ 2000 \mathrm{~d}(1976)$. The language differs from that eventually enacted as title IX in two respects. First, title VI prohibits "race, color, or national origin" discrimination rather than sex discrimination; second, it applies to "any program or activity" receiving federal funds rather than only educational programs or activities. See text accompanying note 23 supra.

45 See H.R. 16098, 91st Cong., 2d Sess. $\$ 805(\mathrm{a})$, reprinted in Discrimination Against Women: Hearings on Section 805 of H.R. 16098 Before the Special Subcomm. on Education of the House Comm. on Education and Labor, 91st Cong., $2 d$ Sess. 1 (1970) [hereinafter cited as 1970 Hearings].

4642 U.S.C. $\$ 2000$ d-3 (1976) provides: "Nothing contained in this subchapter shall be construed to authorize action under this subchapter by any department or agency with respect to any employment practice of any employer, employment agency, or labor organization except where a primary objective of the Federal financial assistance is to provide employment."

47 See 1975 Hearings, supra note 9, at 409 (statement of Congressman O'Hara). Simply adding the word "sex" to title VI would have prohibited genderbased discrimination in any program receiving federal monies; title IX, in contrast, is limited to educational programs. The rationale for this modification was explained by the Supreme Court in Cannon v. University of Chicago, 441 U.S. 677, 694-95 nn.16 \& 17 (1979).

During hearings before the House Special Subcommittee on Education, it became clear that sex discrimination complaints involved primarily educational institutions. 1970 Hearings, supra note 45 . The narrower amendment that eventually became title IX was designed to address such complaints, Cannon, 441 U.S. at 694-95 n.16, and to recognize the impact that schools and colleges have on the development of individuals in our society. See notes 108-10 infra \& accompanying text.

4840 Fed. Reg. 24,134 (1975) (emphasis added).

49 See note 46 supra \& accompanying text. 
pear in the original House-passed version, ${ }^{50}$ but it was removed by the conference committee that had to reconcile the House and Senate bills. The only record of this deletion appears in the conference reports:

In addition, the House amendment, but not the Senate amendment, provided that nothing in the title authorizes action by any department or agency with respect to any employment practice of any employer, employment agency, or labor organization except where a primary objective of the Federal financial assistance is to provide employment. The House recedes. ${ }^{51}$

ED points to this recision as direct authority for its employment regulations. ${ }^{52}$ Most courts, however, have concluded that the em(1971).

50 H.R. 7248, 92d Cong., Ist Sess. $\$ 904,117$ Cong. Rec. 39354, 39365

51 S. REP. No. 798, 92d Cong., 2d Sess. 221, reprinted in [1972] U.S. CoDE CONG. \& AD. NEws 2608, 2671-72. The same description appears in the House Conference Report. H.R. REP. No. 1085, 92d Cong., 2d Sess. 221 (1972).

52 Brief for Federal Appellants at 30-31, North Haven Bd. of Educ. v. Hufstedler, 629 F.2d 773 (2d Cir. 1980); accord, 1975 Hearings, supra note 9, at 329 (statement of Dr. Bernice Sandler).

ED claims further support for its position by analogizing the title IX employment coverage issue to that considered in United States v. City of Chicago, 395 F. Supp. 329 (N.D. Ill.), aff'd mem., 525 F.2d 695 (7th Cir. 1975). That case involved a termination of revenue sharing funds under $\$ 122(a)$ of the State and Local Assistance Act of 1972, another statute patterned after title VI but excluding title VI's employment exemption. Section 122(a) provided that "[n]o person in the United States shall, on the ground of race, color, national origin, or sex, be excluded from participation in, be denied the benefits of, or be subjected to discrimination under any program or activity funded in whole or in part with funds made available under [the Act]." Pub. L. No. 92-512, §122(a), 86 Stat. 932 (current version at 31 U.S.C. $\$ 1242$ (a) (1) (1976)). A preliminary injunction was issued against Treasury Department officials, prohibiting them from making additional revenue sharing payments to the City of Chicago after prima facie evidence was found that "the City's police department had engaged in sexually and racially discriminatory policies and practices in respect to the employment and promotion of police officers." $395 \mathrm{~F}$. Supp. at 342 . The City argued that, because $\S 122$ (b), Pub. L. No. $92-512, \S 122$ (b), 86 Stat. 932 (current version at 31 U.S.C. $\$ 1242$ (b) (2) (1976) (deleting provision relevant here)), permitted the Treasury Secretary to exercise the powers provided in title VI, and title VI clearly excludes employment, federal funds could not be terminated on the grounds of employment discrimination. The court rejected this argument, stating "[t] $]$ hat [the] restriction in the Act of 1964 [the title VI employment exemption] cannot be regarded as limiting the explicit language of Section 122(a) of the 1972 Revenue Sharing Act." 395 F. Supp. at 344. Similarly explicit language appears in title IX, enacted just four months before the revenue sharing statute.

The First Circuit, however, rejected ED's reliance on City of Chicago, in Islesboro School Comm. v. Califano, 593 F.2d 424, 429-30 (1st Cir.), cert. denied, 444 U.S. 972 (1979). The court described the revenue sharing act as embodying "an entirely different legislative scheme" in which the participants and beneficiaries of the program are the employees of the direct beneficiaries of the program-the city's police, fire or other departments. In contrast, the court found, funds ex- 
ployment exemption was eliminated to correct a simple drafting error. ${ }^{53}$ As part of a larger legislative package when introduced, title IX included amendments to title VII of the Civil Rights Act of 1964 and to the Equal Pay Act.54 Each of these laws affects employment practices, and the package therefore would have been internally inconsistent had a broadly worded employment exemption-applicable, ostensibly, to the entire package-been included in one section..$^{55}$

There is no simple resolution to this debate; both sides have presented plausible reasons for the deletion of the employment exemption. The opposing views, however, need not rest upon this preliminary stalemate. Proponents of title IX's employment coverage ask why a more limited exemption, applicable only to those sections currently referred to as title IX, was not substituted for the deleted section. Such a provision could have excluded employment coverage while eliminating any drafting mistake.56 Moreover, no drafting error was noted in the conference report. In response, opponents of ED's employment regulations argue that merely removing the employment exemption does not imply employment coverage; explicit coverage of employees is required. ${ }^{57}$ These addi-

pended for educational programs are intended to benefit students. Id. 430; cf. Brunswick School Bd. v. Califano, 449 F. Supp. 866, 874 (D. Me. 1978), affd sub nom. Islesboro School Comm. v. Califano, 593 F.2d 424 (1st Cir.), cert. denied, 444 U.S. 972 (1979) ( $\$ 122$ (a) of Revenue Sharing Act differs from title IX because title IX has extensive list of coverage exclusions and was part of legislative package that included provisions covering employment discrimination).

This distinction is not persuasive. Teachers may participate in and benefit from educational programs to the same extent that police officers participate in and benefit from city police departments. The ultimate beneficiaries of education are the students, but the ultimate beneficiary of police protection is the public.

53 See, e.g., Romeo Community Schools v. HEW, 600 F.2d 581, 584 (6th Cir.), cert. denied, 444 U.S. 972 (1979); Islesboro School Comm. v. Califano, 593 F.2d 424, 428 (Ist Cir.), cert. denied, 444 U.S. 972 (1979). See also Kuhn, supra note 10 , at 57 .

54 See notes 114-15 infra \& accompanying text.

55 Romeo Community Schools v. HEW, 600 F.2d 581, 584 (6th Cir.), cert. denied, 444 U.S. 972 (1979); Islesboro School Comm. v. Califano, 593 F.2d 424, 428 (Ist Cir.), cert. denied, 444 U.S. 972 (1979).

56 North Haven Bd. of Educ., 629 F.2d at 783.

57 To support this argument, opponents can cite the Justice Department's 1970 proposal for combating sex discrimination in educational institutions. That draft bill not only excluded the employment exemption, but also added a new subsection expressly prohibiting employment discrimination. See 1970 Hearings, supra note 45, at 677-78, 690-91 (statement of Jerris Leonard). See also Brief of Plaintiff-Appellees at 22-23, North Haven Bd. of Educ. v. Hufstedler, 629 F.2d 773 (2d Cir. 1980). But see note 52 supra.

Opponents of employment coverage also argue that title VI, after which title IX is patterned, see notes $44-48$ supra \& accompanying text, was not intended to cover employment practices even without its employment exemption. They contend that the employment exemption now found in $\$ 2000 \mathrm{~d}-3$ of title VI was added 
tional arguments clarify the importance of the employment exemption, but they do not conclusively indicate Congress's intention concerning the scope of title IX.

\section{Congressional Debate}

Statements made by members of Congress during the relevant floor debates are another aid in the search for legislative intent. Although it is dangerous to rely too heavily on casual statements made during such debates, ${ }^{58}$ the views of the chief sponsors of any legislation are entitled to some weight. ${ }^{59}$ This is especially true when, as here, the law eventually enacted was introduced as an amendment on the Senate floor and no useful committee reports are available. ${ }^{10}$ Statements made by Senator Bayh, the chief sponsor of title IX, should be examined closely, therefore, in determining whether Congress intended title IX to reach employment discrimination. ${ }^{61}$

There is no doubt that Senator Bayh's remarks about title IX frequently referred to employment discrimination. ${ }^{62}$ Those courts finding little significance in these statements, however, conclude that the Senator was always referring to the entire title IX legisla-

during the legislative debate for clarification purposes only. See 110 Cong. REc. 12720 (1964) (statement of Senator Humphrey) ("This provision . . . serves to spell out more precisely the declared scope of the title."). But see notes 143-54 infra \& accompanying text.

58 See Schwegmann Bros. v. Calvert Distillers Corp., 341 U.S. 384, 396 (1951) ( Jackson, J., concurring).

59 "It is the sponsors that we look to when the meaning of the statutory words is in doubt." National Woodwork Mfrs. Ass'n v. NLRB, 386 U.S. 612, 640 (1967) (quoting Schwegmann Bros. v. Calvert Distillers Corp., 341 U.S. 384, 394-95 (1951)); 2A J. SutherLAND, supra note 24, at $\$ 48.15$. Each court considering whether Congress intended title IX to cover employment discrimination has given some weight to Senator Bayh's statements made during the floor debates. See cases cited in notes $15,18, \& 19$ supra.

60 House committee reports and floor debates are of little value because they largely ignored the employment issue. See, e.g., H.R. REP. No. 554, 92d Cong., 1st Sess. 51-52, 108-09, reprinted in [1972] U.S. CodE Cong. \& AD. NEws 2462, 2511-12, 2566-67; 117 Cong. REc. 39248-63. The House version of title IX, in fact, contained an employment exemption until it was removed by the conference committee. See notes $49-51$ supra \& accompanying text.

61 One concern traditionally expressed about a sponsor's construction of an amendment is that he or she has an incentive to make statements calculated to improve chances of the bill's passage. $2 \mathrm{~A} \mathrm{~J}$. SuTHERLAND, supra note 24 , at $\$ 48.15$. In this case, if Senator Bayh had wanted to slant his statements to improve title IX's chances of passing, he would have slanted them toward limited coverage and against the inclusion of employment. Any evidence that Senator Bayh intended his amendment to cover employment, therefore, is entitled to some weight.

62 See, e.g., text accompanying notes 65,67 , \& 74 infra. 
tive package, including the title VII and Equal Pay Act amendments. ${ }^{63}$ Analyzing several of the disputed statements in chronological order illustrates the ambiguity troubling the courts.

Senator Bayh first introduced title IX in 1971 as an amendment to a higher education bill then being debated. At that time, no changes to any employment-related statute were included in his amendment. ${ }^{64}$ Nonetheless, his description of the amendment prominently mentioned employment discrimination: "While over 50 percent of our population is female, there is no effective protection for them as they seek admission and employment in educational facilities. .. . Today, women seeking employment in higher education face an array of obstacles almost as insuperable as those which used to face blacks." 65

During the next session, Senator Bayh reintroduced his amendment in a proposal that also extended coverage of title VII and the Equal Pay Act to educational institutions. ${ }^{66}$ Upon the introduction of his modified amendment, Senator Bayh made the following comments:

Amendment No. 874 is broad, but basically it closes loopholes in existing legislation relating to general education programs and employment resulting from those programs. ... More specifically, the heart of this amendment is a provision banning sex discrimination in educational programs receiving Federal funds. The amendment would cover such crucial aspects as admissions procedures, scholar-

63 See, e.g., Romeo Community Schools v. HEW, 600 F.2d 581, 585 (6th Cir.), cert. denied, 444 U.S. 972 (1979); Islesboro School Comm. v. Califano, 593 F.2d 424, 427-28 (Ist Cir.), cert. denied, 444 U.S. 972 (1979). See notes 54-55 supra \& accompanying text.

64 Amend. No. 398 to S. 659, 92d Cong., 1st Sess., 117 Cong. Rec. 30155-57 (1971).

65 117 Cong. Rec. 30155-56 (1971) (emphasis added). See Senator McGovern's supporting statements citing employment statistics in educational institutions. Id. 30158. Senator McGovern had his own sex discrimination amendent to offer, which expressly covered employment, but he threw his support behind the Bayh amendment. See id. 30411. No vote was taken on Senator Bayh's amendment because it was ruled nongermane. Id. 30413-15.

Given that title IX was not part of a legislative package at the time of Senator Bayh's 1971 statements, see notes 64-65 supra \& accompanying text, the courts denying employment coverage have not provided an adequate explanation for these earlier employment references. Indeed, no court other than the Second Circuit has directly addressed these 1971 statements. See North Haven Bd. of Educ., 629 F.2d at 779. It is conceivable, however, that between congressional sessions, Senator Bayh and his cosponsors decided that employment discrimination in educational institutions could be handled more effectively through other means-that is, by amending title VII and the Equal Pay Act. See text accompanying note 73 supra.

66118 CONG. REC. 5802 (1972). 
ships, and faculty employment, with limited exceptions. Enforcement powers include fund termination provisionsand appropriate safeguards-parallel to those found in title VI of the 1964 Civil Rights Act. Other important provisions in the amendment would extend the equal employment opportunities provisions of title VII of the 1964 Civil Rights Act to educational institutions, and extend the Equal Pay for Equal Work Act to include executive, administrative and professional women. ${ }^{67}$

Most courts have interpreted the above references to employment discrimination, as well as other employment-related statements made after Senator Bayh introduced his modified amendment, as applying to the entire legislative package. ${ }^{88}$ The Second Circuit, however, disputed this reading. As Judge Oakes noted, "Senator Bayh in his quoted remarks quite clearly referred to 'faculty employment' in conjunction with the basic prohibition of his amendment and then referred to the '[o]ther important provisions' dealing with Title VII and the Equal Pay Act." ${ }^{89}$

Similar distinctions have been made in judicial interpretations of the summary of title IX ${ }^{70}$ inserted into the record by Senator Bayh prior to the statute's enactment. ${ }^{71}$ The headings provided in the summary-"A. Prohibition of Sex Discrimination in Federally Funded Education Programs" and "B. Prohibition of Education-Related Employment Discrimination"-seem to reflect the dichotomy between title IX and the remainder of the legislative package that has been noted by the majority of courts. ${ }^{72}$ Under the first heading, however, Senator Bayh specifically noted that " $\mathrm{t}]$ his portion of the amendment covers discrimination in all areas where abuse has been mentioned-employment practices for faculty and administrators, scholarship aid, admissions, access to programs within the institution such as vocational education classes, and so forth." 73

The last passage of the debate to which $\mathrm{ED}$ points for support of its employment regulations is a colloquy between Senators Bayh

67 Id. 5803 (emphasis added).

68 See, e.g., cases cited in note 63 supra.

69 North Haven Bd. of Educ., $629 \mathrm{~F} .2 \mathrm{~d}$ at 780 (emphasis in original).

70118 Cong. Rec. 5806-08 (1972).

71 Compare North Haven Bd. of Educ., 629 F.2d at 780-81 with Islesboro School Comm. v. Califano, 593 F.2d 424, 428 (Ist Cir.), cert. denied, 444 U.S. 972 (1979) and Romeo Community Schools v. HEW, 600 F.2d 581, 585 (6th Cir.), cert. denied, 444 U.S. 972 (1979).

72 See note 63 supra \& accompanying text.

73118 CoNG. REc. 5807 (1972) (emphasis added). 
and Pell, chairman of the Senate Subcommittee on Education and floor manager of the entire education bill:

Mr. Pell. . . [Section 1681 of title IX] include[s] all educational institutions which receive Federal assistance. This includes elementary and secondary schools as well. With regard to private undergraduate colleges, the Senator has excluded from coverage their admissions practices. Does the same exclusion apply to nonpublic institutions at the elementary and secondary level?

Mr. BAYH. At the elementary and secondary levels, admissions policies are not covered. As the Senator knows, we are dealing with three basically different types of discrimination here. We are dealing with discrimination in admission to an institution, discrimination of available services or studies within an institution once students are admitted, and discrimination in employment within an institution, as a member of a faculty or whatever.

In the area of employment, we permit no exceptions. In the area of services, once a student is accepted within an institution, we permit no exceptions. The Senator from Rhode Island asked about admissions policies of private secondary and primary schools. They would be excepted.

MR. Pell. . . . [D]o I understand the Senator to say that the faculty of private schools would have to reflect a sexual balance?

Mr. BAYH. This amendment sets no quotas. It only guarantees equality of opportunity. The Senator from Indiana cannot be sure about the sexual balance in any faculty, but as far as employment opportunities are concerned, the answer would be "Yes." 74

Senator Pell's questions clearly seem related to those sections of the bill that are now within title IX. The above colloquy suggests, therefore, that Senator Bayh understood the prohibitory sections of his amendment to cover employment practices. Most courts, however, consider this to be a strained interpretation. ${ }^{75}$ They concede that Senator Bayh's responses may have been more expansive than necessary, but this is explained by the inherent imprecisions in oral

74 Id. 5812-13.

75 See, e.g., Islesboro School Comm. v. Califano, 593 F.2d 424, 427 (Ist Cir.), cert. denied, 444 U.S. 972 (1979). 
debate. $^{76}$ Moreover, it is inaccurate, if not unfair, to remove statements from their general context. The totality of Senator Bayh's remarks, they conclude, show that only the modifications to title VII and the Equal Pay Act were intended to affect employment. ${ }^{77}$

Ultimately, examining isolated statements from congressional debate, even statements attributed to the chief sponsor of the bill, is an unsatisfying if not deceptive way to determine legislative intent. There is no certain way to determine if Senator Bayh and the majority of Congress intended title IX to reach employmentfor each remark that implies employment coverage, others exist that suggest the opposite result. ${ }^{78}$ Pre-enactment legislative history thus is not determinative of congressional intent concerning the scope of title IX.

\section{B. Post-Enactment}

That Congress continued to concern itself with the scope of title IX even after its enactment is not unusual; the legislature is expected to follow and react to the consequences of its previous actions. ${ }^{79}$ Post-enactment statements or actions by Congress or its members should be surveyed, therefore, to determine whether references have been made to employment coverage under title IX, and if so, to determine the weight properly accorded to such references. Three separate areas of congressional action will be considered briefly: first, an analysis of title IX inserted into the record by Senator Bayh; second, Congress's failure to disapprove the employment regulations issued by $\mathrm{ED}$; and third, various attempts by individual members of Congress to limit title IX's employment coverage.

One month after title IX was passed, Senator Bayh submitted an analysis of the statute into the record.80 This analysis, prepared by the Association of American Colleges, summarized the legal requirements imposed by title IX. Although post-enactment expla-

$76 \mathrm{See}$, e.g., id.

$77 \mathrm{See}$, e.g., id.

78 As Chief Justice Marshall so aptly explained in another context, "where the mind labours to discover the design of the legislature, it seizes every thing from which aid can be derived." United States v. Fisher, 6 U.S. (2 Cranch) 358, 386 (1805).

79 "Legislative oversight of administration is a familiar and well-grounded assumption of responsible government. Accepted, too, is the corollary that the need for such oversight increases with executive initiative in policy and the delegation of discretion under the broad terms of statutes. . .." Macmahon, Congressional Oversight of Administration: The Power of the Purse, in LEGISLATtve Polrtics U.S.A. 185 ( 2 d ed. T. Lowi 1965).

80118 CoNG. REC. 24683-85 (1972). 
nations by individual members of Congress are entitled to "little or no weight" when interpreting statutes, ${ }^{81}$ it is interesting to note that this analysis clearly included employment within the scope of the title. ${ }^{82}$

A more significant part of the "subsequent legislative history" followed ED's promulgation of the title IX regulations in June 1975.83 Under the General Education Provisions Act (GEPA), ${ }^{84}$ ED was required to submit its final title IX regulations to both houses of Congress at the same time it published them in the Federal Register. Congress then had forty-five days to pass a concurrent resolution to keep the regulations from taking effect. ${ }^{85}$ The applicable standard was whether "the final regulation is inconsistent with the Act from which it derives its authority." 86

ED followed this procedure, noting, however, that the executive branch had grave reservations about the practicality and the constitutionality of the legislative veto procedure. ${ }^{87}$ In the Senate, no action beyond the introduction of several disapproval resolutions was taken. ${ }^{88}$ In the House, the Subcommittee on Postsecondary

81 Tennessee Valley Auth. v. Hill, 437 U.S. 153, 209 (1978); accord, Southeastern Community College v. Davis, 442 U.S. 397, 411 n.11 (1979); Regional Rail Reorganization Cases, 419 U.S. 102, 132 (1974). But see North Haven Bd. of Educ., 629 F.2d at 782 .

s2 "Title VI also specifically excludes employment from coverage (except where the primary objective of the federal aid is to provide employment). There is no similar exemption for employment in the sex discrimination provisions relating to federally assisted education programs." 118 CoNG. REc. 24684 n.I (1972) (emphasis in original).

83 See note 9 supra.

8420 U.S.C. $\$ \S 1221-1233 \mathrm{~h}(1976)$.

8520 U.S.C. $\$ 1232$ (d)(1) (1976). The forty-five day period is adjusted for periods of adjournment. Id. $\S 1232(\mathrm{~d})(2)$. The agency may modify a regulation if a concurrent resolution of disapproval is passed; in propounding a modified regulation, the agency must "indicate how the modification differs from the proposed regulation... earlier disapproved, and how the agency believes the modification disposes of the findings by Congress in the concurrent resolution of disapproval." Id. $\S 1232(\mathrm{e})$. These provisions are explicitly applicable to title IX and its regulations. Id. $\$ 1232(f)$.

$86 I d$. $\$ 1232$ (d) (I).

871975 Hearings, supra note 9, at 6-7, 441, 460-62 (letter and testimony of HEW Secretary Weinberger); accord, Statement on the Education Amendments of 1974, in 1974 PuB. Papers 35, 37. The controversy surrounding the legislative veto is beyond the scope of this Comment, but many articles have discussed the issues. See, e.g., Bruff \& Gellhorn, Congressional Control of Administrative Regulation: A Study of Legislative Vetoes, 90 Harv. L. Rev. 1369 (1977); Schwartz, The Legislative Veto and the Constitution-A Reexamination, 46 GEo. WAsh. L. REv. 351 (1978); Watson, Congress Steps Out: A Look at Congressional Control of the Executive, 63 CaIIF. L. REv. 983 (1975).

88 Only one of those resolutions was relevant to employment coverage under title IX, and that was a blanket disapproval submitted by Senator Helms. The North Carolina Senator did specifically mention the alleged invalidity of the employment regulations when introducing his resolution. S. Con. Res. 46, 94th Cong., 
Education held six days of hearings to consider ED's regulations. ${ }^{89}$ By far, the most controversial subject during the hearings was the application of the regulations to intercollegiate athletics. ${ }^{90} \mathrm{~A}$ few statements disagreeing with the employment regulations were made, ${ }^{91}$ but most witnesses addressing the issue supported that portion of the regulations addressing employment practices. ${ }^{92}$ A resolution of disapproval was reported out to the full committee, but it objected to only three provisions-the self-evaluation procedures imposed on institutions, the grievance procedures imposed on institutions, and the provision requiring religious institutions to apply for exemption. ${ }^{93}$ The full Committee on Education and Labor returned the resolution to its Subcommittee on Equal Opportunities where its demise was certain. ${ }^{94}$ That subcommittee held a one-day hearing and recommended rejection of the resolution. ${ }^{95}$

Courts considering the validity of ED's title IX employment regulations have disagreed on the significance of this congressional inaction. Several possible interpretations can be suggested. First, the legislative failure to disapprove the regulations can be taken as

lst Sess., 121 Conc. Rec. 17301 (1975) (statement of Senator Helms) ("While it was the obvious intent of the statute that it apply to those seeking an educational opportunity, the regulations cover the employees of educational institutions, whether they be maintenance personnel, administrative staff or teachers. Again, the regulations are inconsistent with the congressional enactment.").

89 See 1975 Hearings, supra note 9.

90 See id. passim.

91 See id. 401-15 (statement and testimony of Janet L. Kuhn). Congressmen O'Hara and Bell expressed agreement with Ms. Kuhn's analysis. Id. 408-09. See also note 10 supra.

92 See, e.g., 1975 Hearings, supra note 9, at 140 (testimony of Jean Simmons, Federation of Organizations for Professional Women), 154-55 (statement of Representative Carr), 164 (testimony of Representative Mink), 173 (testimony of Senator Bayh), 329 (statement of Dr. Bernice Sandler, Association of American Colleges), 466 (testimony of HEW Secretary Weinberger).

93 H.R. Con. Res, 330, 94th Cong., Ist Sess. (1975), reprinted in Hearing on House Concurrent Resolution 330 (Title IX Regulation) Before the Subcomm. on Equal Opportunities of the House Comm. on Education and Labor, 94th Cong., 1st Sess. 2 (1975) [hereinafter cited as Concurrent Resolution Hearings].

94 Even if the subcommittee had made its recommendations to the full committee on the same day that the resolution of disapproval was returned to it, the resolution would have had to be approved by the full committee, the Rules Committee, the full House, and the Senate within a week. It was unlikely that Congress would meet this timetable, and in fact, it did not. See 31 Cong. Q. Almanac 664 (1975).

95 See Concurrent Resolution Hearings, supra note 93. Representative Martin also introduced a broad disapproval resolution to void the employment regulations. See H.R. Con. Res. 310, 94th Cong., 1st Sess., 121 Cong. REc. 19209 (1975). For a more exacting description of the House committee proceedings, see Comment, HEW's Regulation Under Title IX of the Education Amendments of 1972: Ultra Vires Challenges, 1976 B.Y.U. L. Rev. 133, 146-48 and 31 Cong. Q. ALMANAG 662-65 (1975). 
congressional approval of the regulations. No authorities support such an interpretation. Second, the congressional failure to disapprove can create a presumption of approval. Although a few authorities may support such a reading, ${ }^{96}$ Congress itself rejected such an interpretation in an amendment to GEPA passed just four months after the title IX regulations became effective. ${ }^{97}$ Third, the failure to disapprove may lend some weight to the conclusion that Congress intended to reach employment practices under title IX. Accepting this interpretation, the Second Circuit concluded that the congressional review of title IX regulations was "not without significance." 98 Finally, the failure to disapprove may be considered irrelevant to a determination of title IX's reach. This is essentially the position taken by the majority of courts deciding the employment coverage issue. ${ }^{99}$

Regardless of the weight given to this legislative inaction, however, several points should be made. It is clear that Congress was aware of the controversy surrounding the employment regulations; yet it did not focus on the issue. It is also certain that Congress's failure to disapprove the regulations does not support the notion that Congress excluded employment from title IX's reach. Ultimately, the failure to pass any disapproval resolutions must be judged in the context of all congressional post-enactment reactions to the statute. For example, several exemptions have been added

98 See, e.g., Costanzo v. Tillinghast, 287 U.S. 341, 345 (1932); Comment, Half-Court Girls' Basketball Rules: An Application of the Equal Protection Clause and Title IX, 65 IowA L. REv. 766, 787-88 (1980) [hereinafter cited as IowA Comment].

97 That amendment added the following language:

Failure of the Congress to adopt such a concurrent resolution with respect to any such final standard, rule, regulation, or requirement prescribed under any such Act, shall not represent, with respect to such final standard, rule, regulation, or requirement, an approval or finding of consistency with the Act from which it derives its authority for any purpose, nor shall such failure to adopt a concurrent resolution be construed as evidence of an approval or finding of consistency necessary to establish a prima facie case, or an inference or presumption, in any judicial proceeding.

Education for All Handicapped Children Act of 1975, Pub. L. No. 94-142, $\$ 7$ (b), 89 Stat. 773, 796 (codified at 20 U.S.C. $\$ 1232$ (d) (I976) (with inaccuracies)), See note 85 supra \& accompanying text.

98 North Haven Bd. of Educ., $629 \mathrm{F.2d}$ at 783. See also IowA Comment, supra note 96, at 787 (congressional "approval" of title IX regulations "cannot be considered unimportant or perfunctory"); YALE Note, supra note 22, at 1262 (Congress's retention of a veto over regulations implies that ED should be allowed to promulgate broad regulations).

99 The courts cite the 1975 amendment to GEPA, note 97 supra, to support their conclusion. See, e.g., Islesboro School Comm. v. Califano, 593 F.2d 424, $428-29$ n.3 (1st Cir.) ("Congressional inaction should not lightly be construed as approval."), cert. denied, 444 U.S. 972 (1979). 
to title IX since its original enactment. ${ }^{100}$ Congressional attempts to limit the employment coverage of title IX, however, have never advanced beyond their introduction by individual members. ${ }^{101}$ Considered together with Congress's failure to enact any of the disapproval resolutions during 1975, this inaction, although not conclusive, suggests that employment coverage was originally contemplated by Congress. ${ }^{102}$

While the legislative history does seem to support employment coverage, such an important question concerning the scope of title IX's remedy should not be decided on such ambiguous evidence. Each extract from the legislative history that appears to prove that Congress intended title IX to reach employment practices can also be explained by other reasoning. The Education Amendments of 1972 were a massive congressional enactment, containing many controversial provisions; the bulk of congressional debate did not even consider the sex discrimination provisions. Moreover, the current version of title IX was amended onto the statute during floor debate and closed conference committee proceedings; ${ }^{103}$ thus, no useful committee reports explaining the provision exist. Such a limited legislative history cannot be dispositive of the title IX employment coverage issue.

\section{Furthering the Purposes Behind Title IX}

Because the plain language and the legislative history of title IX are inconclusive, it is necessary to ask whether employment coverage under title IX is consistent with the broad remedial purposes underlying the statute's enactment. ${ }^{104}$ As Justice Frankfurter commented:

100 Subsection 1681(a)(6) was added in 1974. Pub. L. No. 93-568, §3(a), 88 Stat. 1862 (1974) (codified at 20 U.S.C. $\$ 1681(\mathrm{a})(6)$ (1976)). Subsections I681(a) (7)-(9) were added in 1976. Pub. L. No. 94-482, title IV, $\$ 412(a)$, 90 Stat. 2234 (1976) (codified at 20 U.S.C. $\$ \$ 1681(a)(7)-(9)(1976)$ ). See note 32 supra.

101 See, e.g., S. 2146, 94th Cong., 1st Sess., 121 Cong. Rec. 23845-47 (1975) (introduced by Senator Helms); Unprinted Amend. No. 389, 94th Cong., $2 d$ Sess., 122 Conc. Rec. 28136-48 (1976) (introduced by Senator McClure).

102 For the view that congressional reactions to regulations should carry more weight if they are based on policy, rather than legal, grounds, see Bruff \& Gellhorn, supra note 87 , at 1429-33.

103 See note 60 supra \& accompanying text.

104 Distinguishing between "legislative intent" and "legislative purpose" has long been the subject of legal, as well as philosophical, discussion. See, e.g., $\mathrm{R}$. DrGkERSON, supra note 25, at 87-88; Landis, A Note on "Statutory Interpretation," 43 Harv. L. Rev. 886, 888 (1930). Throughout this Comment, "intent" refers to the particular application of a statute that Congress desired, as evidenced by the legislative history. "Purpose," on the other hand, refers to the "general aim or 
[T] he purpose which a court must effectuate is not that which Congress should have enacted, or would have. It is that which it did enact, however inaptly, because it may fairly be said to be imbedded in the statute, even if a specific manifestation was not thought of, as is often the very reason for casting a statute in very general terms.

Often the purpose or policy that controls is not directly displayed in the particular enactment. Statutes cannot be read intelligently if the eye is closed to considerations evidenced in affiliated statutes, or in the known temper of legislative opinion. ${ }^{105}$

The social policy considerations motivating Congress when title IX was enacted in 1972 are well-known. ${ }^{106}$ Sex discrimination was a prime target of congressional action that year, ${ }^{107}$ and employment discrimination in educational institutions was of particular concern to the legislators who enacted title IX. Congress realized that deep-rooted changes in society are often first attempted in our

policy which pervades a statute." Cox, Judge Learned Hand and the Interpretation of Statutes, 60 Harv. L. Rev. 370, 370 (1947). Professor Cox has provided a useful example:

In enacting the Fair Labor Standards Act . . . it was the "purpose" of Congress to raise the standard of living of workers engaged in interstate commerce or in the production of goods for commerce. When it defined production to include "any process or occupation necessary to the production thereof," Congress "intended" . . . to make the act applicable to maintenance workers in the executive offices of interstate producers.

Id. 371 (footnotes omitted). Such a distinction is especially appropriate when discussing title IX because the Supreme Court has already used a similar analysis in this area. In Cannon v. University of Chicago, the Court applied four factors to determine if Congress intended to make the title IX remedy available to private litigants. 441 U.S. 677, 688 \& n.9 (1979) (citing Cort v. Ash, 422 U.S. 66, 78 (1975)). To examine the second factor-whether there is any indication of legislative intent, explicit or implicit, to create or deny such a remedy-the Court looked to the legislative history of title IX. Id. 694-703. When examining the third factor-whether a private right of action is consistent with the underlying purposes of the legislative scheme-the Court looked to the objectives of title IX. Id. 703-06. See notes 120-22 infra \& accompanying text. Cf. United Steelworkers v. Weber, 443 U.S. 193, 201 (1979) ("The prohibition against racial discrimination in . . . Title VII must therefore be read against the background of the legislative history of Title VII and the historical context from which the Act arose.").

Courts addressing the title IX employment coverage issue generally have found the language or legislative history of the statute to be determinative, and have failed, therefore, to examine sufficiently the congressional purposes underlying title IX. See, e.g., North Haven Bd. of Educ. v. Hufstedler, 629 F.2d 773, 784-85 (2d Cir. 1980); Romeo Community Schools v. HEW, 438 F. Supp. 1021, 1032 , 1034 (E.D. Mich. 1977), aff'd, 600 F.2d 581, 584-85 (6th Cir.), cert. denied, 444 U.S. 972 (1979).

105 Frankfurter, supra note 23 , at 539 .

106 See 1970 Hearings, supra note 45; YALE Note, supra note 22, at 1264 n.69 ("Certainly, the basic purpose and policy of Title IX was to eliminate sex discrimination and sex stereotyping in education.").

${ }^{107}$ See note 2 supra \& accompanying text. 
educational institutions. ${ }^{108}$ Teachers, administrators, indeed all employees working in educational institutions have a tremendous impact on the ultimate prejudices of their students. Our schools "are the laboratories in which the prejudice of our children are [sic] reinforced or dispelled, their stereotypes shaped or discarded, their expectations instilled, and in which the aspirations of a new generation are crushed or encouraged." 109 When students see female teachers under the control of male administrators, impressions are created that are difficult to combat. ${ }^{110}$ The same sex stereotyping occurs when only a few women are members of a university's faculty, or when discrimination against school guidance counselors results in gender-based career advice to students.

If eliminating discrimination is important anywhere, then, it is in the realm of education because the effects of employment discrimination are potentially more devastating in this context than in any other. ${ }^{111}$ The Ninety-second Congress recognized this fact, and made the eradication of sex stereotyping in education a primary

108 The same idea was expressed by the Supreme Court in Brown v. Board of Educ., 347 U.S. 483 (1954).

109 Runyan, Employment Decision-Making in Educational Institutions, 26 Wanne L. Rev. 955, 1018 (1980). See also Note, Teaching Woman Her Place: The Role of Public Education in the Development of Sex Roles, 24 Hastings L.J. 1191,1191 (1973) ("Through an intricate web of formal and informal educational processes, ... . schools impose upon girls a restricting set of sexual stereotypes that discourage their aspirations and limit their sense of autonomy and self-image.").

110 See, e.g., Commissioner's Task Force, Office of Education, A Look at Women in Education, reprinted in The Women's Educational Equity Act: Hearings on H.R. 208 Before the Subcomm. on Equal Opportunities of the House Comm. on Education and Labor, 93d Cong., lst Sess. 57, 59 (1973) (footnote omitted) ("[W]hen children look at adult roles in their own schools, .... they are likely to see that women teach and men run things: and [sic] early and potentially damaging lesson in 'career education.' For while 85 percent of all public school elementary teachers are women, 79 percent of the elementary school principals are men.") [hereinafter cited as 1973 Hearings].

111 Throughout the litigation in this area, ED has argued that, even if title IX does not authorize regulation of employment directly, the agency can prohibit sex discrimination in employment to the extent that it constitutes discrimination against students. See, e.g., Brief for Federal Appellants at 46-49, North Haven Bd. of Educ. v. Hufstedler, 629 F.2d 773 (2d Cir. 1980). This so-called "infection theory" is similar to, but more limited than, the argument made in this Comment that Congress intended title IX to reach all employment practices because employees in educational institutions have a major impact on the ultimate prejudices of students. See notes 108-10 supra \& accompanying text.

The infection theory is supported by several cases recognizing its use in the prohibition of racial discrimination under title VI. In United States v. Jefferson County Bd. of Educ., for example, the Fifth Circuit recognized that, even with an employment exemption, title VI authorizes some regulation of teachers and faculty. The court explained that "[i]ntegration of faculty is indispensable to the success of desegregation plan [sic]. Nor can we impute to Congress the intention to license, unconstitutionally, discrimination in the employment and assignment of teachers, a conspicuous badge of de jure segregated schools." 372 F.2d 836, 885-86 (5th Cir. 1966), adopted en banc per curiam, 380 F.2d 385 (5th Cir.), 
goal.112 The House hearings that initiated title IX included much evidence on the detrimental effects that employment discrimination in schools could have both on the employees, and more importantly, on the students. ${ }^{113}$ To combat these adverse effects, Congress amended both title VII ${ }^{114}$ and the Equal Pay Act ${ }^{115}$ to

cert. denied, 389 U.S. 840 (1967). Three years later, the Fifth Circuit further articulated this basis for employment regulation under title VI:

Clearly the racial composition of a school's ... faculty may have an effect upon the particular program in question. But this may not always be the case. In deference to that possibility, the administrative agency seeking to cut off federal funds must make findings of fact indicating either that a particular program is itself administered in a discriminatory manner, or is so affected by discriminatory practices elsewhere in the school system that it thereby becomes discriminatory.

Board of Pub. Instruction v. Finch, 414 F.2d 1068, 1079 (5th Cir. 1969); accord, Caulfield v. Board of Educ., 583 F.2d 605, 610-11 (2d Cir. 1978).

$E D$ suggests that having a disproportionate number of males in administrative positions, compensating females at a lower rate than their male counterparts, or discriminating against female guidance counselors infects students when they become aware of such practices or utilize such services. It argues that the infection theory, therefore, should be accepted under title IX. Brief for Federal Appellants at 47-49, North Haven Bd. of Educ. v. Hufstedler, 629 F.2d 773 (2d Cir. 1980). Most courts addressing the infection theory in the context of title IX have not considered it necessary to discuss the merits of this contention, however, because ED's regulations are general in nature and are not limited to discriminatory employment practices affecting students. See, e.g., Islesboro School Comm. v. Califano, 593 F.2d 424, 430 (Ist Cir.) ("while the basic premise [of the infection theory] might be correct, that does not adequately underpin a grant of authority to [ED] to promulgate broad-ranging regulations canvassing employment-related discrimination."), cert. denied, 444 U.S. 972 (1979); Seattle Univ. v. HEW, I6 Fair Empl. Prac. Cas. 719, 722 (W.D. Wash. 1978), affd per curiam, 621 F.2d 992 (9th Cir. 1980), cert. granted sub nom. United States Dep't of Educ. v. Seattle Univ., 49 U.S.L.W. 3409 (U.S. Dec. 1, 1980) (No. 80-493); Romeo Community Schools v. HEW, 438 F. Supp. 1021, 1034-35 (E.D. Mich. 1977), aff'd, 600 F.2d 581 (6th Cir.), cert. denied, 444 U.S. 972 (1979). The Second Circuit found the broad ED regulations valid and enforceable and thus also did not reach the infection issue. North Haven Bd. of Educ., 629 F.2d at 777-86; cf. 34 C.F.R. $\$ 100.3(c)(3)$ (1980) (title VI regulation allowing employment coverage if some effect on beneficiaries can be demonstrated). But see Caulfield v. Board of Educ., 486 F. Supp. 862, 885 (E.D.N.Y. 1979) (infection theory accepted under title IX), aff'd, 24 Empl. Prac. Dec. II 31,270 (2d Cir. 1980).

112 See YAIE Note, supra note 22, at 1264-69. See also 118 Cong. Rec. 5804 (1972) (statement of Senator Bayh); 1973 Hearings, supra note 110, at 180-93 (Final Report of Sex Roles Stereotypes Project).

113 See, e.g., 1970 Hearings, supra note 45, at 147 (resolutions passed by National Organization for Women), 178-79 (platform on women's rights of New Democratic Coalition), 214 (article by Dr. Ann Scott), 435-39 (statement of Daisy Shaw, Director of Educational and Vocational Guidance of New York City), 586, 607 (statement by Women's Rights Committee of New York University Law School), 1081 (paper on status of women at Cornell University).

114 The amendment to title VII was originally included as $\$ 1005$ of Senator Bayh's amendment. 118 CoNG. Rec. 5803 (1972). That amendment was ultimately deleted in favor of one passed as part of the Equal Employment Opportunity Act, Pub. L. No. 92-261, 86 Stat. 103 (amending 42 U.S.C. $\$ 2000$ (a) (1970)).

115 Pub. L. No. 92-318, $\$ 906$ (b), 86 Stat. 375 (amending 29 U.S.C. $\$ 213$ (a) (1970)). 
include educational employment practices. It also enacted title IX-whose broad, sweeping provisions would be especially effective in countering the severe, and perhaps irremediable, impact of employment discrimination in the nation's educational institutions.

Opponents of title IX's employment coverage argue thatgiven title VII, ${ }^{116}$ the Equal Pay Act, ${ }^{117}$ and Executive Order Number 11,246, as amended ${ }^{118}$-Congress did not intend to add another sanction against employee-related sex discrimination in the educational context.119 As this Comment will demonstrate, however, these alternative remedies lack the clout of title IX-and are therefore inadequate in combatting sex discrimination in our schools, the institutions in which the devastating effects of sex stereotyping are most deeply felt.

\section{A. The Necessity of the Title IX Sanction}

The Supreme Court has already had one opportunity to consider the sweeping coverage of title IX. In Cannon v. University of Chicago,"120 the Court noted that "[t]itle IX ... sought to accomplish two related, but nevertheless somewhat different, objectives. First, Congress wanted to avoid the use of federal resources to support discriminatory practices; second, it wanted to provide individual citizens effective protection against those practices." ${ }^{121}$

The second purpose noted by the Supreme Court was effectuated in Cannon when the Court implied a private right of action under title IX.122 The first purpose-avoiding the discriminatory

11642 U.S.C. $\$ \$ 2000 \mathrm{e}$ to $2000 \mathrm{e}-17$ (1976, Supp. I 1977 \& Supp. II 1978).

11729 U.S.C. $\$ 206$ (d) (1976).

118 Exec. Order No. 11,246, 3 C.F.R. 339 (1964-65 Compilation), as amended by Exec. Order No. 11,375, 3 C.F.R. 684 (1966-70 Compilation) and Exec. Order No. 11,478, 3 C.F.R. 803 (1966-70 Compilation), reprinted in 42 U.S.C. $\$ 2000$, at $1232(1976)$.

119 See, e.g., Romeo Community Schools v. HEW, 438 F. Supp. 1021, 1034, aff'd, 600 F.2d 581 (6th Gir.), cert. denied, 444 U.S. 972 (1979).

120441 U.S. 677 (1979).

121 Id. 704. For portions of the congressional debate identifying these two objectives see $i d$. 704 n.36 (citing 117 Cong. REc. 39252 (1971) (statement of Representative Mink) and 118 CoNG. REc. 5806-07 (1972) (statement of Senator Bayh)). For a criticism of the Supreme Court's analysis of title IX's purposes, see Comment, A Private Right of Action Under Title IX: Cannon v. University of Chicago, 57 DEN. L.J. 437, 449-51 (1980).

122 Cannon, 441 U.S. at 705-06.

The plaintiff in Cannon was a female applicant who was denied admission to medical school. Id. 680. The Cannon opinion, therefore, was concerned with alleged student-related discrimination, and did not address the potential employment 
use of federal monies-is "generally served by the statutory procedure for the termination of federal financial support for institutions engaged in discriminatory practices." 123 None of the other statutes proscribing sex discrimination in employment provide such a sweeping remedy.

Of course, title VII does prohibit certain employment practices that discriminate on the basis of sex, ${ }^{124}$ and the Equal Pay Act prohibits gender-based wage discrimination. ${ }^{125}$ Both laws are interpreted and enforced by the Equal Employment Opportunity Commission (EEOG). ${ }^{126}$ The EEOG is authorized to investigate complaints, determine whether unlawful discrimination has occurred, and if it has, negotiate a voluntary settlement or file suit

coverage of title IX. But of. Sobel v. Yeshiva Univ., 477 F. Supp. 1161, 1167-68 (S.D.N.Y. 1979) (employees not within the benefited class of title IX; thus, no private right of action for employees). Should title IX be found to reach employment practices, a conflict may arise between a plaintiff's immediate access to the courts under title IX and the broad range of administrative and procedural requirements imposed on those who file complaints under title VII or the Equal Pay Act. See generally 29 C.F.R. $\$ 1601$ (1979); 29 C.F.R. $\$ 800$ (1979). Indeed, it might be argued that this conflict supports the claim that Congress did not intend to cover employment under title IX. Although Congress may have considered the ramifications of its employment coverage in the event that the courts implied a private right of action, see Cannon, 441 U.S. at 703, it is the judiciary which implies private rights of action, and it is also the judiciary which should deal with the potential conflict. For example, courts can conclude that the explicit policies represented by congressional enactment of title VII and the Equal Pay Act are controlling, and therefore, no private actions under title IX are possible for employee-related discrimination. Alternatively, a title VII or Equal Pay Act exhaustion requirement could be imposed on potential plaintiffs, or the courts can simply consider the title IX sanction another overlapping remedy. See note 134 infra. At most, now that a private right of action has been inferred for at least one class of plaintiffs, Congress may want to amend title IX, limiting private suits to those alleged victims of sex discrimination who do not have recourse to title VII or the Equal Pay Act. In any case, these individual remedies, however framed, are not sufficient to fulfill the primary congressional motive behind title IX. See note 134 infra and text accompanying note 133 infra.

123 Cannon, 441 U.S. at 704 (footnote omitted).

12442 U.S.C. $\$ 2000 \mathrm{e}-2$ (1976).

12529 U.S.C. $\$ 206$ (d) (1976). Because the Equal Pay Act is limited to wage discrimination, it "does not provide a vehicle for moving women into nontraditional jobs, nor does it address the need to upgrade the status and pay of jobs traditionally held by women." Greenberger, The Effectiveness of Federal Laws Prohibiting Sex Discrimination in Employment in the United States, in Equad EMrlomaent Policy for Women 108, 118 (R. Ratner ed. 1980). The Act thus cannot solve the problem of sex stereotyping in our educational systems. See notes 108-10 supra \& accompanying text.

12642 U.S.C. $\$ 2000$ e-5 (1976) (title VII); Reorg. Plan No. 1 of 1978, 3 C.F.R. 321 (1978 Compilation), reprinted in 5 U.S.C. app., at 354 (Supp. III 1979) (Equal Pay Act). The EEOC has not been aggressive in enforcing title VII or the Equal Pay Act against sex-related discrimination, primarily due to an insufficient budget, inadequate staffing, and administrative ineptitude. See Greenberger, supra note 125, at 111, 118 . 
against the employer. ${ }^{127}$ The EEOC has no authority under title VII or the Equal Pay Act, however, to seek the termination of any federal funds that the institution might be receiving. Thus, the remedies allowed under these laws, even the broad injunctive and affirmative relief allowed under title $\mathrm{VII},{ }^{128}$ provide little incentive for educational institutions to voluntarily eliminate all employment practices that discriminate on the basis of sex. ${ }^{229}$

Executive Order Number $11,246,130$ on the other hand, does accomplish some aspects of the title IX sanction. The order requires that all recipients of federal contracts submit to an affirmative action plan if one is needed to remedy past discrimination; ${ }^{131}$ the relevant agency can cancel all government contracts and eliminate future bidding rights if the contractor does not comply. The Department of Labor's Office of Federal Contract Compliance Programs can administer these sanctions against colleges and universities. The order, however, applies only to those institutions that are government contractors, ${ }^{132}$ a category that rarely, if ever, includes elementary and secondary schools or other types of educational institutions covered under title IX. Executive Order Number

12729 U.S.C. $\$ \$ 211(\mathrm{a}), 216$ (b) (1976 \& Supp. III 1979) (Equal Pay Act); 42 U.S.C. $\$ 2000 \mathrm{e}-5$ (1976) (title VII).

Under the Equal Pay Act, the EEOC may conduct compliance investigations without a prior complaint. Moreover, individual employees may sue their employers directly for alleged wage discrimination. Under title VII, however, an individual wishing to sue his or her employer must first file a complaint with the EEOC. If the EEOC fails to act within a specified time period, the individual may obtain a "right to sue letter" from the agency, and proceed to sue the employer directly. If the plaintiff wins, the discriminating employer may be required to bear the costs of the suit, including the plaintiff's attorney's fees. Private individuals and groups, however, often lack the financial resources to initiate direct suits, and many attorneys are reluctant to handle employment discrimination suits against employers. Moreover, harassment of many complainants discourages prlvate suits. See Greenberger, supra note 125, at 108, 111-13.

128 See, e.g., 42 U.S.C. $\$ 2000 \mathrm{e}-5(\mathrm{~g})$ (1976).

129 There are no penalties available under title VII or the Equal Pay Act. The Equal Pay Act does provide for liquidated damages equal to the amount of back pay. See 29 U.S.C. \$216(b) (Supp. III 1979). Even an employer who expects to lose, therefore, benefits by waiting to be sued because he or she has the use of the funds required to change a discriminatory practice or pay any back wages due. See generally Greenberger, supra note 125, at 110-11, 118.

130 See note 118 supra.

131 To the extent that affirmative action is required, the executive order goes beyond title IX.

132 The percentage of the 3,100 colleges and universities covered by title IX, see National Center on Education Statistics, Education Directory, Colleges \& UNIVERSTrIES xxviii (1978-79), that falls within the mandate of the executive order, is not readily ascertainable. It is likely, however, that most of the two-year institutions (approximately 1,200) and some of the remaining four-year institutions are not government contractors. 
11,246 thus is not sufficiently broad in its coverage to meet the goal of eliminating sex discrimination in educational institutions.

In enacting title IX, Congress hoped to fill the void left in the education area by the "important, but usually piecemeal, sanctions" ${ }^{133}$ provided by title VII, the Equal Pay Act, and Executive Order Number 11,246. ${ }^{134}$ Society's goal of eradicating sex discrimination-and thus sex stereotyping-from the nation's educational institutions can be achieved only if the government has the ultimate power to terminate the education funds available to a discriminatory institution. The Fifth Circuit has explained the need for this more forceful approach in discussing title VI and the problem of school desegregation:

Congress was dissatisfied with the slow process inherent in the judicial adversary process. Congress therefore fashioned a new method of enforcement to be administered not on a case by case basis as in the courts but generally, by federal agencies operating on a national scale and having a special competence in their respective fields. Congress looked to these agencies to shoulder the additional enforcement burdens resulting from the shift to high gear .... . ${ }^{135}$

Termination of educational funds for violations of title IX is, of course, a drastic sanction. Congress thus provided that it be a sanction of last resort; ${ }^{138}$ the primary enforcement method of title IX is voluntary compliance. The statute permits use of the termination sanction only if "compliance cannot be secured by voluntary means." 137 Moreover, many layers of procedural safeguards protect

133 North Haven Bd. of Educ., 629 F.2d at 785.

134 Even if these alternative remedies were more appropriately designed to achieve the stated congressional purpose, title IX could still be used to remedy employment discrimination. The Supreme Court has consistently recognized that "legislative enactiments in this area have long evinced a general intent to accord parallel or overlapping remedies against discrimination." Alexander v. GardnerDenver Co., 415 U.S. 36, 47 (1974); accord, Johnson v. Railway Express Agency, Inc., 421 U.S. 454, 459 (1975). See North Haven Bd. of Educ., 629 F.2d at 784-85. On the general ineffectiveness of title VII and the Equal Pay Act, see Greenberger, supra note 125.

135 United States v. Jefferson County Bd. of Educ., 372 F.2d 836, 853 (5th Cir. 1966) (footnote omitted), cert. denied, 389 U.S. 840 (1967).

136 Cannon, 441 U.S. at $705 \&$ n.38; id. 719-20 (White, J., dissenting). Senator Bayh suggested that ED "would be reasonable and would use only such leverage as was necessary against the institution. . . [T] [Te Secretary would be expected to use good judgment as to how much leverage to apply, and where it could best be applied." 117 Cong. Rec. 30408 (1971).

13720 U.S.C. $\$ 1682$ (1976). 
the alleged discriminatory institution. ED's regulations had to be issued in proposed form, subjected to public comments, redrafted by $\mathrm{ED}$, reissued in final form, approved by the President, and reviewed by the Congress before they could bccome effective. ${ }^{138}$ The regulations require that each institution establish appropriate selfevaluation and grievance procedures. ${ }^{139}$ Should ED not be able to secure voluntary compliance through a negotiated settlement, it must make an express finding, after giving the institution an opportunity for a hearing, that the institution failed to comply with title IX.140 Thereaftcr, ED must file a full report with the relevant House and Senate committees, and thirty days must pass without any formal action by the Congress. ${ }^{141}$ Finally, the statute explicitly provides for judicial review of any action taken by ED. ${ }^{142}$ Title IX was enacted, therefore, not as a punitive measure, but as a lever to be used against discriminatory educational institutions. Institutions that discriminate on the basis of sex are threatened with a cutoff of federal funds unless appropriate changes are made. Indeed, it is this potential threat that makes title IX so different from, yet so complementary to, the alternative remedies available for employment discrimination.

\section{B. Contrasting Political Climates: Title VI and Title IX}

Opponents of title IX employment coverage argue that, because title VI provides for a fund cutoff sanction but clearly does not reach employment, ${ }^{143}$ Congress cannot be said to consider such a sanction necessary for eliminating employment discrimination. Race-based employment discrimination is as invidious as sex discrimination, and it too needs the forceful sanction that a potential cutoff of funds provides. Two explanations account for this seeming contradiction. First, as previously discussed, ${ }^{144}$ title IX- unlike title VI-is limited to educational programs, an area in which employment discrimination is especially harmful. ${ }^{145}$ Second, the

138 See notes 9-11 supra \& accompanying text.

13934 C.F.R. $\$ \S 106.3$ (c)-3(d), 106.8(b) (1980).

14020 U.S.C. $\$ 1682$ (1976).

$141 \mathrm{Id}$.

14220 U.S.C. $\$ 1683$ (1976). For a summary discussion of these safeguards, see Hunter, Federal Antibias Legislation and Academic Freedom: Some Problems With Enforcement Procedures, 27 EMORY L.J. 609, 615-16 (1978).

143 See notes 49-57 supra \& accompanying text.

144 See notes 108-10 supra \& accompanying text.

145 It can also be argued that educational programs are distinct from other federally funded programs because such large amounts of federal funds are ex- 
political situation in 1964 required that an employment exemption ${ }^{146}$ be added to title VI in order to end a Senate filibuster, whereas no such compromise was necessary in 1972.147

When trying to explain the absence of an employment exemption in title IX, opponents of ED's employment coverage have suggested that title VI was not intended to cover employment even without its employment exemption. They assert that the exemption was added to title VI for clarification purposes only. ${ }^{148}$ This reading of title VI's legislative history, however, is shortsighted. The employment exemption in title VI was amended onto the statute as part of a substitute written during informal bargaining between the Senate's Democratic and Republican leadership with the intention of providing a compromise that would garner enough votes to end the ongoing filibuster. ${ }^{149}$ Because title VI was brought directly to the Senate floor after it passed the House, no exhaustive committee reports explaining its provisions exist. ${ }^{150}$ Senator Humphrey, however, as majority whip and floor manager of the bill,

pended on salaries and other expenses relating to the employees of educational institutions. For example, many federal research grants go directly to employees. Most courts have already recognized title IX coverage for recipients of these funds. See note 28 supra. The Second Circuit noted that the North Haven school board uses between $46.8 \%$ and $66.9 \%$ of its federal funds to pay salaries of its employees, North Haven Bd. of Educ., 629 F.2d at 774-75, although no special significance was explicitly attached to this fact. The Fifth Circuit noted in Dougherty County School Sys. v. Harris that a substantial portion of the federal aid received by the school went toward salaries of home economics and vocational education teachers. 622 F.2d 735, 738 (5th Cir. 1980). This evidence led that court to conclude that more limited regulations prohibiting sex discrimination among employees who have a specific relationship to federal educational funds or programs may be authorized by title IX. Id. 737-38. See notes 19-20 supra \& accompanying text. There is no evidence, however, that Congress distinguished between education and other federally funded programs on the basis of their dependence on federal monies; nor is there any suggestion in the legislative history that employees can be differentiated according to their connections with federal funds.

146 See note 46 supra.

147 See notes $149,152-54$ infra \& accompanying text. $C f$. United Steelworkers v. Weber, 443 U.S. 193, 206 (1979) ("Title VII could not have been enacted into law without substantial support from legislators in both Houses who traditionally resisted federal regulation of private business. Those legislators demanded [a compromise] as a price for their support ....").

148 See note 57 supra.

149 The Mansfield-Dirksen substitute was introduced on May 26, 1964.110 Conc. REc. 11926 (1964). Cloture of the filibuster was voted on June 10, 1964. 110 Cong. REc. 13327 (1964). The Civil Rights Act passed the Senate on June 19, 110 Cong. Rec. 14511 (1964), passed the House on July 2, 110 Cong. Rec. 15897 (1964), and was signed by the President on the same day. Civil Rights Act of 1964, Pub. L. No. 88-352, 78 Stat. 241 (codified at 42 U.S.C. $\$ \$ 2000 \mathrm{a}-2000 \mathrm{~h}$ (1976)).

1502 Statutony History of the UntTed States: CivIL Rights 1089-90 (B. Schwartz ed. 1970) [hereinafter cited as Schwartz]. 
provided his colleagues with detailed analyses of the bill before and after the substitute was introduced. Comparing these two summaries demonstrates that the employment exemption did result in substantive changes to title VI's coverage. ${ }^{151}$

Congress in 1972 was confronted with a completely different political situation. Many enactments prohibiting sex discrimination were easily passed during that year. ${ }^{152}$ Title IX itself was passed in the Senate by a voice vote. ${ }^{153}$ The only amendments made to title IX concerned limited exceptions to its coverage; ${ }^{154}$ in contrast to the situation in 1964, no further compromise was necessary. A majority of Congress was concerned primarily with eliminating sex discrimination with as few limitations as possible. In such an atmosphere, it is difficult to imagine that Congress did not intend to cover employment discrimination under title IX.

\section{The "Innocent Victims" of Title IX}

Section 1682 of title IX allows ED only two courses of action when it finds sex discrimination in a recipient educational institu-

151 After the Mansfield-Dirksen substitute was introduced, Senator Humphrey noted that the employment exemption "serves to spell out more precisely the declared scope of coverage of the title." 110 Cong. Rec. 12720 (1964). This language suggests that no substantive changes were made in title VI. Before the employment exemption existed, however, Senator Humphrey had this to say about title VI's employment coverage:

In such cases the Commissioner [of Education] might also be justified in requiring elimination of racial discrimination in employment or assignment of teachers, at least where such discrimination affected the educational opportunities of students ....

This does not mean that title VI would authorize a Federal official to prescribe pupil assignments, or to select a faculty, as opponents of the bill have suggested. The only authority conferred would be authority to adopt, with the approval of the President, a general requirement that the local school authority refrain from racial discrimination in treatment of pupils and teachers and authority to achieve compliance with that requirement by cutoff of funds or by other means authorized by law.

110 Cong. Rec. 6545 (1964) (emphasis added). The legislative history thus indicates that the addition of an employment exemption to title VI did have a substantive effect on the title's reach. Other summaries of the changes made by the Mansfield-Dirksen substitute conform to this analysis. See, e.g., 110 Conc. REC. I4220 (1964) (statement by Senator Holland) ("Substantive changes are made in [the section adding the employment exemption].").

A more detailed examination of title VI's legislative history is beyond the scope of this Comment. See generally Schwartz, supra note 150.

162 For example, the final version of the Equal Employment Opportunity Act of 1972, Pub. L. No. 92-261, 86 Stat. 103 (codified in scattered sections of 5, 42 U.S.C.), passed the Senate by a vote of 62 to 10, 118 Cong. REc. 7170 (1972), and the House by a vote of 303 to 110,118 Cong. REc. 7572-73 (1972).

153118 CONG. REc. 5815 (1972).

154 See note 32 supra. 
tion. ${ }^{105}$ ED must either seek to terminate the federal funds of the discriminatory program by complying with all the procedural requirements necessary for such a cutoff, ${ }^{150}$ or use "any other means authorized by law," including a referral of the case to the Justice Department for proceedings to enforce federal law or government contracts with nondiscrimination provisions. ${ }^{157}$ These limited enforcement provisions have led most courts to conclude that the termination of federal funds, and thus the application of title IX, is justified only when the students are themselves the victims of sex discrimination. 158 In such a case, the benefits that "students might derive from the education programs financed by [ED are] more than outweighed by the sex discrimination in those programs." ${ }^{159}$ A termination of funds in a case in which only employees are victims of discrimination, on the other hand, would hurt innocent students by eliminating their educational programs when there has been no violation of their rights. Moreover, a fund cutoff would undoubtedly lead to the layoff of teachers and other staff. ${ }^{160}$ Because it is unlikely that Congress would support an enforcement mechanism that injures the primary beneficiaries of federal educational programs, without enforcing their rights, the argument continues, Congress could not have intended to cover employment discrimination under title IX. ${ }^{161}$

This seemingly logical argument, however, is in several respects inaccurate and inconsistent. It assumes a narrow and unrealistic view of the innocent victims of any fund cutoff. Given a finding of student-related discrimination, a termination of funds is the ultimate sanction. Such a sanction applies to the entire institution or program involved, thereby cutting off funds even with respect to students who are not being discriminated against. ${ }^{162}$ Thus, some

10520 U.S.C. $\$ 1682$ (1976).

156 See text accompanying notes $140-41$ supra.

15734 C.F.R. $\$ 106.91$ (1980) (interim procedures incorporating 34 C.F.R. $\$ 100.8(\mathrm{a})$ (1980)). See Cannon, 441 U.S. at 722 \& n.9 (White, J., dissenting).

158 See, e.g., Junior College Dist. v. Califano, 455 F. Supp. 1212, 1214-15 (E.D. Mo. 1978), aff'd, 597 F.2d 119 (8th Cir.), cert. denied, 444 U.S. 972 (1979); Romeo Community Schools v. HEW, 438 F. Supp. 1021, 1032-33 (E.D. Mich. 1977), aff'd, 600 F.2d 581 (6th Cir.), cert. denied, 444 U.S. 972 (1979).

159 Romeo Community Schools v. HEW, 438 F. Supp. 102I, 1032 (E.D. Mich. 1977), aff'd, 600 F.2d 581 (6th Cir.), cert. denied, 444 U.S. 972 (1979).

160 Seattle Univ. v. HEW, 16 Fair Empl. Prac. Cas. 719, 721 (W.D. Wash. 1978), aff'd per curiam, 621 F.2d 992 (9th Cir.), cert. granted sub nom. United States Dep't of Educ. v. Seattle Univ., 49 U.S.L.W. 3409 (U.S. Dec. 1, 1980) (No. 80-493).

161 See cases cited in notes 158-60 supra.

162 North Haven Bd. of Educ., 629 F.2d at 785. 
students will be the innocent victims of a sanction imposed due to student-related discrimination. Moreover, such a cutoff of funds will hurt the staff involved in the programs. Unless these employees are responsible for the student-related discrimination, they too will be innocent victims.

The potential cutoff of funds after a finding of employeerelated discrimination leads to analogous results. In that case, a fund cutoff likely will affect both victim-employees and uninvolved employees and have an adverse impact on innocent students. Just as cutoffs caused by employee-related discrimination may hurt uninvolved employees and innocent students, cutoffs caused by student-related discrimination will hurt uninvolved students and innocent employees. ${ }^{163}$

That both of these situations may appear undesirable should not concern the courts. Congress has decided that the benefits students may obtain from programs in which there is sex discrimination are sufficiently outweighed by the social costs of such discrimination. Thus, federal funds must be cut off, even if innocent students may be injured in the process. ${ }^{164}$ This analysis applies equally to the problem of employment discrimination in these programs. Employee-related gender-based discrimination injures students as much as discrimination directed solely at students. The congressional prohibition of sex discrimination expressed in title IX ${ }^{165}$ therefore requires that both types of funding cutoffs be permitted if complete elimination of sex discrimination in educational programs is to be achieved.

In practical terms, federal funds are rarely terminated because many procedural safeguards protect the alleged violators of title IX ${ }^{166}$ and because the funding cutoff is a sanction of last resort, used primarily as leverage against the discriminating institution.167 There is little opportunity, therefore, for the so-called innocent victim problem to arise.

163 The only argument distinguishing these two cases is that some of the employees may be responsible for the student-related discrimination, while it is unlikely that any students will be responsible for employee-related discrimination. But it is unlikely that Congress intended that its policy be interpreted based upon such a fine distinction.

164 See, e.g., Romeo Community Schools v. HEW, 438 F. Supp. 1021, 1032 (E.D. Mich. 1977), aff'd, 600 F.2d 581 (6th Cir.), cert. denied, 444 U.S. 972 (1979).

165 See text accompanying note 23 supra.

16620 U.S.C. \$1682 (1976). See notes 137-42 supra \& accompanying text.

167 See note 136 supra \& accompanying text. 


\section{CONCLUSION}

Until recently, the government's use of title IX to prohibit gender-based employment discrimination seemed to be coming to an undesirable halt. With the recent opinions of the Second and Fifth Circuits, however, new momentum has gathered in support of such employment coverage, and the Supreme Court recently granted certiorari in United States Department of Education $v$. Seattle University ${ }^{168}$ to decide the issue. Unfortunately, none of the lower courts considering the scope of title IX have examined adequately the purposes underlying the enactment of the statute. Rather, they have come to differing conclusions by disagreeing over interpretations of the language and legislative history of title IX.

This Comment has shown that both of these traditional indicia of legislative intent are ambiguous and inconclusive. The congressional motives behind the enactment of title IX, on the other hand, are far from unclear. Congress was particularly concerned about the adverse impact that employment discrimination has in an educational setting. The powerful threat of a fund termination, supplemented by whatever individual remedies are available, is the only way that sex discrimination and its detrimental effects can be completely eliminated from our educational systems. Only title IX can provide such an effective sanction. The statute should therefore be held to cover employment discrimination and the ED regulations found valid and enforceable.

16849 U.S.L.W. 3409 (U.S. Dec. 1, 1980) (No. 80-493).

After this Comment went to press, petitions for certiorari were filed in North Haven Bd. of Educ. v. Hufstedler, 629 F.2d 773 (2d Cir. 1980), petition for cert. filed, 49 U.S.L.W. 3467 (U.S. Dec. 16, 1980) (No. 80-987) and Dougherty County School Sys. v. Harris, 622 F.2d 735 (5th Cir. 1980), petition for cert. filed sub nom. Hufstedler v. Dougherty County School Sys., 49 U.S.L.W. 3495 (U.S. Dec. 22, 1980) (No. 80-1023). 